\title{
DEVELOPMENT OF LIPOSOMAL DRUG FORMULATIONS: QUALITY ATTRIBUTES AND METHODS FOR QUALITY CONTROL
}

\author{
Melnikova EV, Goryachev DV, Chaplenko AA $\bowtie$, Vodyakova MA, Sayfutdinova AR, Merkulov VA
}

Scientific Centre for Expert Evaluation of Medicinal Products

of the Ministry of Health of the Russian Federation, Moscow

\begin{abstract}
The use of nanostructured components in drug manufacturing and, more specifically, targeted drug delivery has recently become a major pharmacy trend. Nanodrugs encompass a wide range of pharmaceutical agents containing dendrimers, nanocrystals, micelles, liposomes, and polymer nanoparticles. Liposomes are the most well-studied nanoparticles and effective drug carriers. However, the more complex their structure is, the more process controls are needed and the more quality attributes have to be monitored, including the chemical properties of the liposomal fraction such as the shape, size and charge of the nanoparticle, conjugation efficacy, and distribution of the active ingredient. We believe that quality control of key liposome characteristics can be carried out using dynamic and laser light scattering coupled with electrophoresis, differential scanning calorimetry, cryo-electron microscopy, nuclear magnetic resonance, laser diffraction analysis, and gel filtration chromatography.
\end{abstract}

Keywords: liposomes, nanodrugs, quality control, guidance documents

$\triangle$ Correspondence should be addressed: Alexander A. Chaplenko

Schukinskaya 6, bl. 1, Moscow, 127051; chaplenko@Expmed.ru

Received: 29.06.2018 Accepted: 02.09.2018

DOI: 10.24075/brsmu.2018.092

\section{РАЗРАБОТКА ЛИПОСОМАЛЬНЫХ ФОРМ ЛЕКАРСТВЕННЫХ ПРЕПАРАТОВ: МЕТОДЫ ОЦЕНКИ И ПОКАЗАТЕЛИ КАЧЕСТВА}

\author{
Е. В. Мельникова, Д. В. Горячев, А. А. Чапленко ®, М. А. Водякова, А. Р. Сайфутдинова, В. А. Меркулов
}

Федеральное государственное бюджетное учреждение «Научный центр экспертизы средств медицинского применения»

Министерства здравоохранения Российской Федерации, Москва

\begin{abstract}
Одним из трендов фрармации на сегодняшний день является применение наноструктурных компонентов для производства лекарств, в частности для направленной доставки лекарственных средств в заданную область организма, органа или клетки. К нанопрепаратам авторы относят средства, содержащие дендримеры, нанокристаллы, мицеллы, липосомы, а также полимерные наночастицы. В настоящее время липосомы - одни из наиболее исследованных наночастиц, которые рассматривают как современные и эффективные средства доставки различных препаратов. Однако увеличение сложности структуры препарата неизбежно приводит к увеличению числа критических точек производства, а также к расширению списка показателей качества. Наряду с классическими показателями качества авторы считают необходимым оценивать также физико-химические свойства липосомной фракции: форму, размер и заряд частиц; эффективность конъюгации маркеров; равномерность распределения действующего вещества. Мы полагаем, что для контроля ключевых параметров липосом целесообразно использовать динамическое и лазерное светорассеяние в сочетании с электрофорезом, дифференциальную сканирующую калориметрию, криорасщепляющую электронную микроскопию, ядерный магнитный резонанс, лазерную дифракцию и гель-фильтрацию.
\end{abstract}

Ключевые слова: липосомы, нанопрепараты, контроль качества, нормативные документы

$\checkmark$ Для корреспонденции: Александр Андреевич Чапленко

ул. Щукинская, д. 6, корп. 1, г. Москва, 127051; chaplenko@Expmed.ru

Статья получена: 29.06.2018 Статья принята к печати: 02.09.2018

DOI: $10.24075 /$ vrgmu.2018.092

Some of the major current challenges before the pharmaceutical industry are regulation of all pharmacokinetic parameters of a drug (absorption, distribution, clearance and biotransformation), ensuring its safety and selective action on target organs and other targets, minimization of undesirable reactions and side effects. Using nanostructured components in general and to deliver drugs to a given body part, organ or cell in particular is one of the trends that sees development today. Russian legislation does not describe the concepts of "nanopreparations" or "nanodrugs"; in reality, all drugs that are nanoparticles or contain them are considered to be such. This definition mainly applies to the drugs based on liposomes and micelles, where nanostructures enable transportation of the active pharmaceutical ingredient inside the body, prolong its absorption, increase stability, etc. Another case are drugs considered to be nanostructured due to the physicochemical characteristics of their active ingredients, an example of which are antianemic iron preparations that may contain iron (III) atoms stabilized by a carbohydrate complex, which defines their nanocolloidal structure. Currently, we are developing quality assessment and research guidelines applicable to drugs based on liposomes and micelles, as well as containing nanoparticles.

Features of the nanodrugs' compositions define the individual approaches to assessing their quality. For example, quality of liposomal preparations largely depends on their individual specific attributes (size of nanoparticles, surface morphology, surface charge), which can affect the following pharmacokinetic and pharmacodynamic properties in vivo: 
- rate of release of the active ingredient from liposomes, a factor that has an effect on pharmacokinetics (PK) and pharmacodynamics (PD) and, consequently, drug's safety profile and efficacy;

- bioavailability of the active pharmaceutical ingredient in liposome, its biotransformation and clearance.

PK of the encapsulated active ingredient depends on that of the carrier, which is determined by the physicochemical properties of the nanoparticle material; interactions between the nanoparticle's components, active ingredient and biological environment (body) should also be taken into account.

We define nanodrugs as drugs that contain dendrimers, nanocrystals, micelles, liposomes and polymeric nanoparticles. Currently, liposome is one of the best-studied nanoparticles among those considered as effective carriers for various drugs. In the recent years, global pharmaceutical industry has developed and released over 20 liposomal drugs primarily used to treat cancer (Dauno Xome (Gilead, NeXstar), Doxil (Alza, Sequus), Couloux (Schering-Plow), Muocet (Elan, TLS)) and fungal infections (AmBisome, ABELSET (Gilead, NeXstar)) [1]. Specific capabilities related to transportation, translocation through histohematogenous barriers and cell membranes, as well as metabolic transformations, provide liposome-based drugs with unique properties that improve their PK.

This article summarizes and analyzes the data describing the use of various types of liposomes for drug delivery and defines the specifics of the liposome-based nanodrugs quality assessment.

\section{Varieties of liposomes and their use by pharmaceutical industry}

Liposomes are vesicles with a lipid bilayer built of amphiphilic molecules enclosing their contents. Recently, liposomes have evolved from a simple model that mimics cell membranes into an object of active research and practical application [2]. In the context of drug delivery, liposomes enable selective accumulation of the active ingredient in pathological lesions (tumors, inflamed tissues) due to their passive targeting ability. This ability is the results of the difference in distance between capillary cells in lesions/tumors and normal tissue: the former, which is 210 to $1000 \mathrm{~nm}$, is significantly greater than the latter, which is approximately $40 \mathrm{~nm}$. Thus, liposomes less than 200 $\mathrm{nm}$ in size cannot escape the bloodstream anywhere except the lesions (with the exception of the brain, where tumors typically have pores of $7-100 \mathrm{~nm}[3,4])$, and the active pharmaceutical ingredient, which can be toxic, is unlikely to contaminate anything but the target. For example, liposomal doxorubicin is $2-3$ times less toxic than the solution of this drug [5].

Using target (endothelial) protein antibodies, which are specific to vessels of various organs, allows manifold improvement of precision of the nanoparticle-enabled delivery of active pharmaceutical ingredients and DNA [6-9].

To date, various researchers have described liposomebased preparations carrying a plethora of active ingredients, $\mathrm{X}$-ray and scintigraphic tracers, toxins, peptides, proteins and nucleic acids. The overwhelming majority of studies in this field has to do with anticancer drugs (most often, anthracyclinebased) [8]. There are five types of liposomes, different in composition and action in vivo, that the researchers preferred, namely: simple liposomes; sterically stabilized liposomes; directed liposomes (immunoliposomes); cationic liposomes; liposomes sensitive to physical and chemical stimuli, such as temperature, light, and changes in $\mathrm{pH}[2,10]$ (Table 1).
When progress in biotechnology and genetic engineering allowed developing a new generation of drugs, such as recombinant proteins, peptides (biotechnological drugs), drugs based on nucleic acids (gene therapy drugs), liposomes acquired a special significance due to the susceptibility of these medicines to chemical and enzymatic hydrolysis [8, 39-41]. In gene therapy, liposome nanocontainers may carry a plasmid with a therapeutic gene sequence, antisense oligonucleotides or small interfering RNAs [42-44]. The volume of the liposomes allows them to contain genes of various sizes [45]. Vector molecules attached to the outer surface of the liposomes target delivery, a mechanism similar to that used for cytotoxic drugs and paramagnetic contrast agents.

When liposomes are used as DNA vaccines, they hold the antigen in their capsule and double as an immunomodulator $[46,47]$. In one of the studies, S-antigen sequence of HBV (pRc / CMV HBS) enclosed in cationic liposomes was used as a DNA vaccine [47]. Balb/c mice received a vaccine of $10 \mu \mathrm{g}$ of plasmid DNA (i.m., per mouse) twice on days 0 and 21. After administration of the native HBsAg, the levels of detectable cytokines in spleens of mice immunized with the liposomebased preparation were 4 times higher than those registered in intact mice and animals vaccinated with DNA, which suggests a possibility of using this liposomal construct as a Hepatitis B vaccine.

Both cationic or anionic liposomes and those with a neutral surface charge can be loaded with DNA. Neutral liposomes circulate in the bloodstream for a much longer period of time than the charged ones; moreover, their advantages are lesser toxicity and non-specific persorption in organs and tissues. However, it is much harder to load them with DNA. In case of passive loading, which is a plain emulsification of lipid components in the presence of DNA, only $10 \%$ of the total amount of DNA gets into the liposomes. There are special techniques that allow increasing the number to $40 \%$, but, as a rule, they also increase the size of the liposomes [45]. Charged liposomes can be loaded with more DNA, which is their key advantage. However, cationic and anionic liposomes have higher levels toxicity and non-specific penetration into organs and tissues than neutral liposomes.

\section{Specifics of the liposome-based drugs quality and production control}

The main stages of production of liposomal drug formulations and the controlled parameters thereof are listed below [48].

1) Lipid film production and its dispersion/degradation. Controlled parameters: amount of residual organic solvents in the lipid film; active pharmaceutical ingredient integration rate and size of the liposomes after lipid film dispersion; stability; $\mathrm{pH}$ value.

2) Production of liposomes of the required size, separating the non-integrated active ingredient, sterilization by filtration. Controlled parameters: amount of the integrated active pharmaceutical ingredient; size of the liposomes; concentration of the lipid components; stability; pH value.

3) Lyophilization. Controlled parameters: residual moisture; stability and percentage of drug integration into the liposomes after lyophilisate rehydration.

The above-listed stages of the technological process allow a conclusion that the critical liposome-based drug quality checks imply determination of its crucial physicochemical properties; therefore, state registration applications for such formulations should provide the following information (Fig. 1). 
Table 1. Use of different types of liposomes for drug delivery

\begin{tabular}{|c|c|c|c|c|c|}
\hline $\begin{array}{l}\text { Types of } \\
\text { liposomes }\end{array}$ & Simple & Sterically stabilized & Immunoliposomes & $\begin{array}{l}\text { Cationic } \\
\text { (lipoplexes) }\end{array}$ & Thermosensitive and photosensitive \\
\hline $\begin{array}{l}\text { Composition } \\
\text { specifics }\end{array}$ & $\begin{array}{l}\text { Phospholipids } \\
\text { (neutral and/or negatively } \\
\text { charged) and/or } \\
\text { cholesterol }\end{array}$ & $\begin{array}{l}\text { Phospholipids }+ \\
\text { polyethylene glycol } \\
\text { (PEG) }\end{array}$ & $\begin{array}{l}\text { Modified PEG-vesicles } \\
\text { conjugated with } \\
\text { monoclonal antibodies } \\
\text { or their fragments, } \\
\text { peptides, growth factors, } \\
\text { glycoproteins, etc. }\end{array}$ & $\begin{array}{l}\text { Positively charged } \\
\text { lipids }\end{array}$ & $\begin{array}{l}\text { Phospholipids the phase transition } \\
\text { temperature of which exceeds body } \\
\text { temperature (thermosensitive). } \\
1,2-B i s(4-(n-b u t y l) p h e n y l a z o-4 '- \\
\text { phenylbutyroyl)phosphatidylcholine } \\
\text { (Bis-Azo PC) in low concentrations } \\
\text { is part of the vesicles of the } \\
\text { photoisomerized lipid molecule. } \\
\text { May be conjugated with PEG or } \\
\text { antibodies (AB) }\end{array}$ \\
\hline $\begin{array}{l}\text { Route of } \\
\text { administration }\end{array}$ & $\begin{array}{l}\text { Oral, injection, inhalation, } \\
\text { local, endovitreal }\end{array}$ & $\begin{array}{l}\text { Injection, } \\
\text { oral }\end{array}$ & Injection & $\begin{array}{l}\text { Injection, } \\
\text { intranasal }\end{array}$ & Injection \\
\hline Half-life & $\begin{array}{l}\text { Several minutes to } 2-3 \\
\text { hours }\end{array}$ & \multicolumn{2}{|c|}{$6-8$ hours to several days } & $\begin{array}{l}\text { Several minutes to } \\
4-6 \text { hours }\end{array}$ & Several days \\
\hline $\begin{array}{l}\text { Key } \\
\text { accumulation } \\
\text { sites }\end{array}$ & \multicolumn{2}{|l|}{ Liver, spleen, lungs } & $\begin{array}{l}\text { Determined } \\
\text { by the attached ligands, } \\
\text { liver, lungs }\end{array}$ & Liver, lungs & Tumor cells \\
\hline Mode of action & Passive targeting & Passive targeting & Directed transport & Passive targeting & Directed transport \\
\hline $\begin{array}{l}\text { Examples } \\
\text { of use }\end{array}$ & $\begin{array}{l}\text { - part of the virus, } \\
\text { antibacterial, parasitic } \\
\text { infection vaccines [11]; } \\
\text { - delivery of } \\
\text { immunomodulators, } \\
\text { cytotoxic and } \\
\text { antimicrobial compounds } \\
\text { to macrophages; } \\
\text { - treatment of } \\
\text { metastases after surgical } \\
\text { removal of primary } \\
\text { tumors } \\
{[12,13] \text {; }} \\
\text { - delivery of drugs } \\
\text { against intracellular } \\
\text { pathogens [14], systemic } \\
\text { fungal infection, HIV, } \\
\text { mycobacterial infection } \\
{[13] ;} \\
\text { - carrying radioisotopes } \\
\text { and contrast agents for } \\
\text { visualization purposes } \\
{[12,13] \text {; }} \\
\text { - carrying antigens } \\
{[12,15]}\end{array}$ & $\begin{array}{l}\text { - accumulation } \\
\text { of drugs in solid } \\
\text { tumors [16-18]; } \\
\text { - treatment of small } \\
\text { cell lung cancer } \\
\text { and cutaneous } \\
\text { melanoma [19], } \\
\text { leukemia and lung } \\
\text { carcinoma }[20,21]\end{array}$ & $\begin{array}{l}\text { - delivery of drug to the } \\
\text { tumor [10, 22-26]; } \\
\text { - treatment of chronic } \\
\text { B-lymphocytic leukemia } \\
\text { and acute T-cell leukemia } \\
\text { [23], various lymphomas } \\
\text { [27]; } \\
\text { - treatment of breast, } \\
\text { thyroid gland, ovarian } \\
\text { cancer, that of uterus, } \\
\text { lung, esophagus, } \\
\text { stomach, colon and } \\
\text { rectum, kidney } \\
{[23,26,28]}\end{array}$ & $\begin{array}{l}\text { - delivery of } \\
\text { the genetic } \\
\text { material to the } \\
\text { liver, cell therapy } \\
\text { of endothelial } \\
\text { pulmonary tumors } \\
{[2,29,30] \text {; }} \\
\text { - antiangiogenic } \\
\text { therapy; } \\
\text { - treatment of } \\
\text { tumors of neck } \\
\text { and head, } \\
\text { melanomas [30] }\end{array}$ & $\begin{array}{l}\text { - delivery of drug } \\
\text { to the tumor }[2,31]\end{array}$ \\
\hline Key advantages & $\begin{array}{l}\text { Penetrate into the } \\
\text { relatively inaccessible } \\
\text { lesions (e.g., in the brain) } \\
\text { due to their negative } \\
\text { charge }[32,33]\end{array}$ & $\begin{array}{l}\text { Contain PEG, which } \\
\text { prevents liposome } \\
\text { opsonization, } \\
\text { hinders their } \\
\text { recognition by the } \\
\text { reticuloendothelial } \\
\text { system cells and } \\
\text { increases the time } \\
\text { of their persistence } \\
\text { in the bloodstream } \\
{[34,35]}\end{array}$ & $\begin{array}{l}\text { Antibodies allow } \\
\text { modulating distribution } \\
\text { of the liposomes in } \\
\text { organs and tissues. } \\
\text { Optimization of the } \\
\text { drug's therapeutic } \\
\text { properties. } \\
\text { Correction of the } \\
\text { effective dose }\end{array}$ & $\begin{array}{l}\text { Penetrate into the } \\
\text { tumor's vessels (as } \\
\text { opposed to neutral } \\
\text { or negatively } \\
\text { charged liposomes) } \\
\text { [36] }\end{array}$ & $\begin{array}{l}\text { Offer greater selectivity } \\
\text { of action compared } \\
\text { to the free drug }[31,37,38]\end{array}$ \\
\hline
\end{tabular}

The behavior of the active pharmaceutical ingredient in a physiological environment is one of the main parameters influencing the liposome-based drug's PK and PD. Therefore, for the purposes listed below it is necessary to develop reliable, validated methods of assessment of the active ingredient release in vitro.

- Monitoring of imitation of the active ingredient release from liposomes in the body; a test for "leakage" in vitro in the relevant environment under various conditions (e.g., in a certain range of temperatures and $\mathrm{pH}$ ) can be conducted given there are grounds for that.

- Monitoring of stability in storage to ensure consistency of lots;

- Investigation of stability and review of the production process in the intended conditions of use.
Table 2 provides an example of the certificate data (key parameters and quality indicators) describing liposomes [49, 50] used for delivery of the therapeutic genes' DNA.

We believe that, depending on the specific function of the liposomes (e.g., modification of the active ingredient's distribution by encapsulation in order to improve the safety profile), the following additional parameters should also be evaluated in the development of the drug:

- maintaining the integrity of the liposomal formulation in plasma;

- characteristics of the lipid bilayer phase transition process (transition temperature and enthalpy);

- determination of the surface charge of the liposomes;

$-\mathrm{pH}$ of the inner chamber of the liposomes filled by the $\mathrm{pH}$ gradient; 


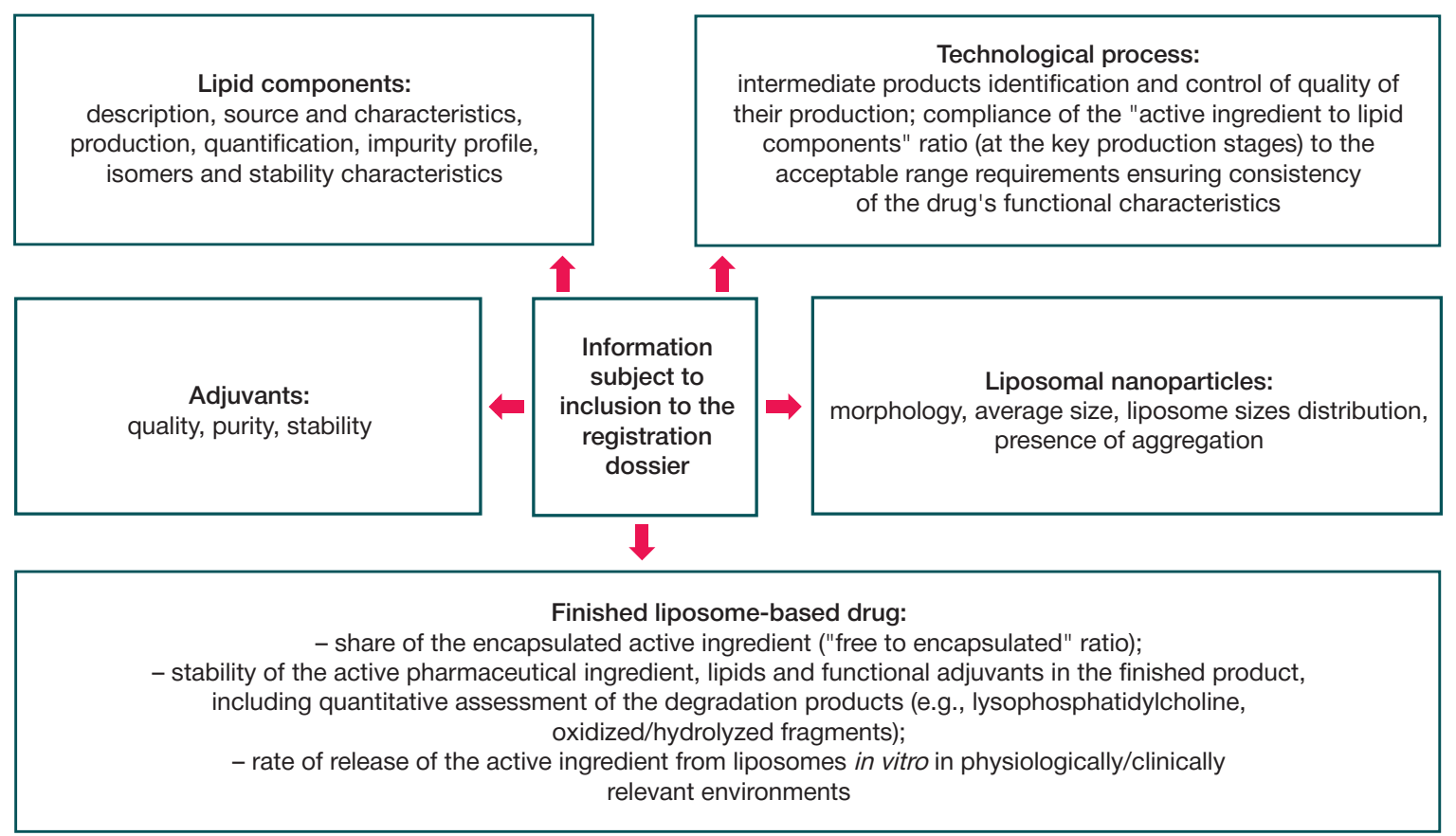

Fig. 1. Information about the quality characteristics of liposomal drug formulations

- if significant, determination of characteristics of the active pharmaceutical ingredient's physical state inside the liposome (e.g., formation of a precipitate for doxorubicin);

- distribution of the active ingredient (e.g., on the surface of liposomes, in the bilayer, internal environment, etc.);

- for conjugated (eg, pegylated) liposome-based preparations: the quality and purity of the pegylated starting material, molecular weight of the conjugated lipid and size distribution (dispersion), location of PEG on the surface, stability of the conjugate.

It is necessary to compile a list of tests each lot should routinely be subjected to. This list should be based on the parameters used to characterize the drug in accordance with the requirements described above.

\section{Legal regulation of liposome-based drugs in the world}

Table 3 provides the examples of requirements regulator bodies from various countries of the world impose on the production, quality control, preclinical and clinical studies of liposomebased forms of drugs.

\section{CONCLUSIONS}

Liposome-based drug delivery systems give a drug designer control over the active ingredient's absorption and release parameters. As a rule, liposome-based drugs are less toxic, pose a lower risk of adverse reactions and allow delivering

Table 2. Liposome-based drugs characteristics

\begin{tabular}{|l|l|l|}
\hline \multicolumn{2}{|c|}{ Parameters } & \multicolumn{1}{c|}{ Analytical/instrumental methods } \\
\hline \multicolumn{2}{|c|}{ Physcal characteristics } \\
\hline 1 & Vesicle size and surface morphology & Electron microscopy \\
\hline 2 & $\begin{array}{l}\text { Distribution of the vesicles sizes (submicron } \\
\text { and micron ranges) }\end{array}$ & Dynamic and laser light scattering, exclusion chromatography (gel filtration) \\
\hline 3 & Surface charge & Dynamic light scattering \\
\hline 4 & Surface pH & pH sensitive samples \\
\hline 5 & Integrated DNA/free preparation percentage & $\begin{array}{l}\text { Methanol-chloroform extraction and centrifugation in separation columns, ion exchange } \\
\text { chromatography, spectrophotometry, radioactive labeling }\end{array}$ \\
\hline \multicolumn{2}{|l|}{ Chemical characteristics } \\
\hline 1 & Phospholipid concentration & Extraction and centrifugation in separation columns \\
\hline 2 & Cholesterol concentration & Extraction and centrifugation in separation columns \\
\hline 3 & Osmolality & Osmometry \\
\hline \multicolumn{2}{|l|}{ Biological characteristics } \\
\hline 1 & Sterility & Pharmacopoeial sterility test \\
\hline 2 & Pyrogenicity & LAL test (Limulus amebocyte lysate test) \\
\hline 3 & Toxicity & In vitro and in vivo monitoring, histology \\
\hline
\end{tabular}


Table 3. Regulatory documents containing requirements to liposomal drug

\begin{tabular}{|c|c|c|}
\hline State & Document & Selected aspects \\
\hline \multirow{3}{*}{ EU countries } & $\begin{array}{l}\text { Reflection paper on the data requirements for intravenous } \\
\text { liposomal products developed with reference to an } \\
\text { innovator liposomal product/21 February } 2013 \mathrm{EMA} \\
\text { CHMP/806058/2009/Rev. 02, Committee for Human Medicinal } \\
\text { Products (CHMP) }\end{array}$ & $\begin{array}{l}\text { Quality control specifics: } \\
\text { - composition and authenticity of the components (lipids, adjuvants); } \\
\text { - active pharmaceutical ingredient to lipids ratio; } \\
\text { - liposomes morphology, average size and size distribution, aggregation; } \\
\text { - fraction of the encapsulated active ingredient (free/integrated amount); } \\
\text { - stability of the active ingredient, lipids, adjuvants, critical } \\
\text { decomposition products; } \\
\text { - in vitro rate of release of the ingredient from liposomes in } \\
\text { physiologically/clinically significant environments; } \\
\text { - stability; } \\
\text { - recovery; } \\
\text { - maintaining integrity of the liposomal formulation in plasma }\end{array}$ \\
\hline & $\begin{array}{l}\text { Recommendations. Commission recommendation } \\
\text { of } 18 \text { October } 2011 \text { on the definition of nanomaterial } \\
\text { (Text with EEA relevance) }(2011 / 696 / E U)\end{array}$ & Definition of nanomaterials \\
\hline & $\begin{array}{l}\text { Reflection paper on surface coatings: general } \\
\text { issues for consideration regarding parenteral } \\
\text { administration of coated nanomedicine } \\
\text { products/22 May } 2013 \text {, EMA/325027/2013, } \\
\text { Committee for Medicinal Products } \\
\text { for Human Use (CHMP) }\end{array}$ & $\begin{array}{l}\text { Key critical quality indicators, as well as the requirements for clinical and } \\
\text { preclinical studies, are included. Special attention is paid to the following } \\
\text { aspects: } \\
\text { - presence of a coating can affect the critical properties of the } \\
\text { nanodrugs from the points of view of their safety and efficacy. The } \\
\text { physico-chemical nature of the coating, uniformity of its surface coating } \\
\text { and stability (both in terms of attachment and in terms of degradation) } \\
\text { will determine the drug's PK and biodistribution; } \\
\text { - in some cases, the coating material may cause new biological } \\
\text { reactions that are not observed either for the coating material or for the } \\
\text { active pharmaceutical ingredients separately }\end{array}$ \\
\hline \multirow[t]{2}{*}{ USA } & $\begin{array}{l}\text { Guidance for Industry. Liposome Drug Products Chemistry, } \\
\text { Manufacturing, and Controls; Human Pharmacokinetics and } \\
\text { Bioavailability; and Labeling Documentation. } \\
\text { - U.S. Department of Health and Human Services Food } \\
\text { and Drug Administration Center for Drug Evaluation } \\
\text { and Research, } 2002\end{array}$ & $\begin{array}{l}\text { Brief description of the liposomes, critical stages of their production } \\
\text { and quality control, recommendations for conducting research on PK } \\
\text { and bioavailability of liposome-based drugs and labeling requirements. } \\
\text { The guideline contains general principles and recommendations for } \\
\text { registration of the drugs of this class. }\end{array}$ \\
\hline & $\begin{array}{l}\text { USP } 41-N F 36<1>\text { Injections and implanted } \\
\text { drug products (parenterals)-product quality tests }\end{array}$ & $\begin{array}{l}\text { Contains definition of liposomes and liposome-based drugs and states } \\
\text { that in the case of liposomes, quality control implies both general and } \\
\text { special tests. }\end{array}$ \\
\hline China & $\begin{array}{l}\text { Pharmacopoeia of the Peoples Republic of China. } \\
\text { Beijing: People's Medical Publishing Hous. } \\
\text { 2010; (2). p. A244-245 }\end{array}$ & $\begin{array}{l}\text { Definitions of various nanoparticles, requirements, nanodrugs quality } \\
\text { control criteria and methods are provided. The attributes that should be } \\
\text { monitored in production and storage of the drugs (e.g., residual amounts } \\
\text { of organic solvents, shape, particle size and distribution, encapsulation } \\
\text { rate and amount of drugs in liposomes, liposome oxidation degree, etc.) } \\
\text { are listed. }\end{array}$ \\
\hline
\end{tabular}

the active ingredient to the target part of the body. Innovative drugs containing liposomes conjugated with antibodies can be targeted with maximum effectiveness and release the active ingredient where needed. However, the more complex the drug's structure becomes, the more crucial stages its production acquires. Moreover, the list of parameters to control, those that determine the quality of the drug, grows. Evaluation of the liposomal fraction's physicochemical properties is added to the classic quality control methods: the shape, size, and charge of the particles are being assessed, as well as marker conjugation effectiveness and uniformity of distribution of the active ingredient. Key methods for estimating the liposome parameters make use of the optical effects: dynamic and laser light scattering, electron microscopy.

\section{References}

1. Krasnopolsky YuM, Stepanov AE, Shvets VI. Technological aspects of production of liposomal preparations under GMP conditions. Biofarm J. 2009; 3: 18-29.

2. Baryshnikov AYu. Nanostructured liposomal systems as a means of delivery of anticancer drugs. Vestnik RAMS. 2012; 3: 23-31.

3. Hobbs SK, Monsky WL, Yuan F. et al. Regulation of transport pathways in tumor vessels: role of tumor type and microenvironment. Proc Natl Acad Sci USA. 1998; 95: 4607-4612.

4. Shvets IV, Kaplun AP, Krasnopolsky YuM. et al. From liposome seventies to nanobiotechnology XXI century. Ross nanotechnologies. 2008; 3 (11-12): 6-20.

5. Love WG, Amos N, Kellaway IW, Williams BD. Specific accumulation of cholesterol-rich liposomes in the inflammatory tissue of rats with adjuvant arthritis. Ann Rheum Dis. 1990; 49 (8): 611-614.

6. Chekhonin VP, Baklaushev VP, Yusubalieva GM. et al. Modeling and immunohistochemical analysis of glioma C6. Cell technol in biol and med. 2007; 2: 65-73.

7. Chekhonin VP, Zhirkov YuA, Gurina Ol. et al. The Pegylated immunoliposome specific to astrocytes. Dokl. RAN. 2003; 391 (6): 1-7.

8. Chekhonin VP, Gurina OI, Dmitrieva TB. Monoclonal antibodies to neurospecific proteins. M.: Medicine, 2007; 344.

9. Errede M, Benagiano V, Girolamo F et al. Differential expression of connexin43 in foetal, adult and tumour-associated human brain endothelial cells. Histochem J. 2002; 34: 265-271.

10. Immordino ML, Dosio F, Cattel L. Stealth liposomes: review of the basic science, rationale and clinical applications, existing and potential. Int J Nanomedicine. 2006; 1 (3): 297-315.

11. Felnerova D, Viret J-F, Gluck R, Moser C. Liposomes and virosomes as delivery systems for antigens, nucleic acids and drugs. Curr Opin Biotechnol. 2004; 15: 518-529. 
12. Barenholz Y. Liposome application: problems and prospects. Curr Opin Colloid Interface Sci. 2001; 6: 66-77.

13. Vasir JK, Reddy MK, Labhasetwar VD. Nanosystems in drug targeting: opportunities and challenges. Curr Nanoscience. 2005; 1 (1): 47-64.

14. Basu MK. Liposomal delivery of antileishmanial agents. J Applied Research. 2005; 5 (1): 221-236.

15. Zurbriggen R, Amacker M, Krammer AR. Immunopotentiating reconstituted influenza virosomes. In: G. Gregoriadis eds. Liposome technology. 3rd edn. Vol. I. Liposome preparation and related techniques. New York: Informa Healthcare USA, 2007; 85-96.

16. Fang J, Sawa T, Maeda H. Factors and mechanism of «epr» effect and the enhanced antitumor effects of macromolecular drugs including smancs. Adv Exp Med Biol. 2003; 519: 29-49.

17. Greish K, Fang J, Inutsuka T. et al. Macromolecular therapeutics: advantages and prospects with special emphasis on solid tumour targeting. Clin Pharmacokinet. 2003; 42: 1089-1105.

18. Maeda $\mathrm{H}$. The enhanced permeability and retention (epr) effect in tumor vasculature: the key role of tumor-selective macromolecular drug targeting. Adv Enzyme Regul. 2001; 41: 189-207.

19. Haley B, Frenkel E. Nanoparticles for drug delivery in cancer treatment. Urologic Oncology: Seminars and Original Investigations. 2008; 26: 57-64

20. Lantsova AV. Creation and biopharmaceutical study of liposomal dosage forms of anticancer drugs derived from nitrosourea. Abstract dis kand farm. sciences. Moscow, 2006; 173.

21. Lantsova AV, Oborotova NA, Peretolchina NM et al. Comparative study of the antitumor activity of the liposomal dosage forms of drugs, derivatives of nitrozomocevina. Sibirs oncologist J. 2005; 2 (14): 25-29.

22. Allen TM. Ligand-targeted therapeutics in anticancer therapy. Nat Rev Cancer. 2002; 2 (10): 750-763.

23. Tolcheva EV. Design of immunoliposomes and study of immunoliposomal form of anticancer drug doxorubicin. Abstract dis kand Biol sciences. M., 2007; 109 p.

24. Sokolova DV, Tazina EV, Kortava MA. et al. Anti-CD40 and antiHLA-DR immunoliposomal form doxorubicin: technology of production and antigen specificity in vivo. Ross biotherapeutic $\mathrm{J}$. 2010; 9 (2): 90.

25. Sokolova DV, Tazina EV, Kortava MA et al. Anti-MUC1 immunoliposomal form of doxorubicin: technology of production and antigen specificity in vitro. Ross biotherapeutic J. 2010; 9 (3): 21.

26. Khugaeva OV, Kortava MA, Sokolova DV et al. Receiving liposomal mitoxantrone/materials of the IX all-Russian. scientific. prakt. Conf. "Domestic anticancer drugs". Ross biotherapeutic J. 2010; 9 (2): 91

27. Nasonov EL. Prospects of rituximab use in autoimmune diseases of a person. Rus Med J. 2007; 15 (26): 1-6.

28. Sokolova DV. Immunoliposomal constructions of doxorubicin and models for their preclinical study. Abstract dis kand Biol sciences. M., 2011; 122

29. Kawakami S, Fumoto S, Nishikawa M et al. In vivo gene delivery to the liver using novel galactosylated cationic liposomes. Pharmaceuttic Research. 2000; 17 (3): 306-313.

30. Dass CR, Choong PFM. Targeting of small molecule anticancer drugs to the tumor and its vasculature using cationic liposomes: lessons from gene therapy. Cancer Cell Int. 2006; 6 (17): 1-9.
31. Ponce AM, Wright A, Dewhirst MW, Needham D. Targeted bioavailability of drugs by triggered release from liposomes. Future Lipidol. 2006; 1 (1): 25-34.

32. Jain $\mathrm{S}$, Mishra $\mathrm{V}$, Singh $\mathrm{P}$ et al. RGD-anchored magnetic liposomes for monocytes/neutrophils-mediated brain targeting. Int J Pharm. 2003; 261 (1-2): 43-55.

33. Qin J, Chen D, Hu H et al. Surface modification of RGD-liposomes for selective drug delivery to monocytes/Neutrophils in brain. Chem Pharm Bull. 2007; 55 (8): 1192-1197.

34. Campbell RB, Fukumura D, Brown EB et al. Cationic charge determines the distribution of liposomes between the vascular and extravascular compartments of tumors. Cancer Res. 2002; 62: 6831-6836.

35. Ambegia $\mathrm{E}$, Ansell $\mathrm{S}$, Cullis $\mathrm{P}$ et al. Stabilized plasmid-lipid particles containing PEG-diacylglycerols exhibit extended circulation lifetimes and tumor selective gene expression. Biochim Biophys Acta. 2005; 1669 (2): 155-163.

36. Dass CR. Improving anti-angiogenic therapy via selective delivery of cationic liposomes to tumor vasculature. Int J Pharm. 2003; $267(1-2): 1-12$

37. Tazina EV, Mescheryakova W, Ignatieva EV et al. Biopharmaceutical studies of temperature-sensitive liposomal formulations of doxorubicin. Ross biotherapeutic J. 2009; 1 (8): 40-47.

38. Huang Z, Szoka FC. Bioresponsive liposomes and their use for macromolecular delivery. In: G. Gregoriadis eds. Liposome technology. 3rd edn. Vol. I. Liposome preparation and related techniques. New York: Informa Healthcare USA, 2007; 165-196.

39. Chekhonin VP, Zhirkov YuA, Aglow NV et al. Directed transport of drugs using liposomes. Vestn RAMS. 2004; 5: 42-47.

40. Wu D, Pardridge WM. Neuroprotection with noninvasive neurotrophin delivery to the brain. Proc Natl Acad Sci USA. 1999; 96: 254-259.

41. Shi N, Pardridge WM. Noninvasive gene targeting to the brain. Proc Natl Acad Sci USA. 2000; 97 (13): 7567-7572.

42. Pal A, Ahmad A, Khan $S$ et al. Systemic delivery of RafsiRNA using cationic liposomes silences Raf in xenograft model of human prostate cancer. Int J Oncol. 2005; 26 (4): 1087-1091.

43. Omidi Y, Barar J, Akhtar S. Toxicogenomics of cationic lipidbased vectors for gene therapy: impact of microarray. Curr Drug Del. 2005; 2 (4): 429-441.

44. Oliveira S, Storm G, Schiffelers. Targeted delivery of siRNA. J Biomed Biotechnol. 2006; 2006: 1-7.

45. Miyazaki M, Obata $\mathrm{Y}, \mathrm{Abe} \mathrm{K}$ et al. Gene transfer using nonviral delivery systems. Perit Dial Int. 2006; 26: 633-640.

46. Aguilar JC. Vaccine adjuvants revisited. Vaccine. 2007; 25: 37523762

47. Perrie Y, Frederik PM, Gregoriadis G. Liposome-mediated DNA vaccination: the effect of vesicle composition. Vaccine. 2001; 19: 3301-3310.

48. Pharmaceutical development: concept and practical recommendations. Scientific-practical guide for the pharmaceutical industry / ed. by Bykov SN, Vasilenko IA, Demina NB, Shokhin IE, Novojilov OV, Meshkovsky AP, Spitskov ORM. Pero, 2015; 472 p.

49. Lu D, Hickey AJ. Liposomal dry powders as aerosols for pulmonary delivery of proteins. AAPS Pharm Sci Tech. 2005; 6 (4): 641-648.

50. De Lima MCP, Simoes $S$, Pires $P$ et al. Cationic lipid-DNA complexes in gene delivery: from biophysics to biological applications. Adv Drug Del Rev. 2001; 47: 277-294.

\section{Литература}

1. Краснопольский Ю. М., Степанов А. Е., Швец В. И. Технологические аспекты получения липосомальных препаратов в условиях GMP. Биофарм журнал. 2009; (3): 18-29.

2. Барышников А. Ю. Наноструктурированные липосомальные системы как средство доставки противоопухолевых препаратов. Вестник РАМН. 2012; (3): 23-31.

3. Hobbs SK, Monsky WL, Yuan F et al. Regulation of transport pathways in tumor vessels: role of tumor type and microenvironment. Proc Natl Acad Sci USA. 1998; (95): 4607-12.
4. Швец В. И., Каплун А. П., Краснопольский Ю. М., Степанов А. Е., Чехонин В. П. От липосом семидесятых к нанобиотехнологии XXI века. Российские нанотехнологии. 2008; 3 (11-12): 6-20.

5. Love WG, Amos N, Kellaway IW, Williams BD. Specific accumulation of cholesterol-rich liposomes in the inflammatory tissue of rats with adjuvant arthritis. Ann Rheum Dis. 1990; 49 (8): $611-14$

6. Чехонин В. П., Баклаушев В. П., Юсубалиева Г. М. Моделирование и иммуногистохимический анализ глиомы С6 
in vivo. Клеточные технологии в биологии и медицине. 2007; (2): $65-73$.

7. Чехонин В. П., Жирков Ю. А., Гурина О. И. ПЭГилированные иммуннолипосомы, специфичные к астроцитам. Докладь Академии наук. 2003; 391 (6): 1-7

8. Чехонин В. П., Гурина О. И., Дмитриева Т. В. Моноклональные антитела к нейроспецифическим белкам. М.: Медицина, 2007; 344 c.

9. Errede M, Benagiano V, Girolamo F et al. Differential expression of connexin43 in foetal, adult and tumour-associated human brain endothelial cells. Histochem J. 2002; (34): 265-71.

10. Immordino ML, Dosio F, Cattel L. Stealth liposomes: review of the basic science, rationale and clinical applications, existing and potential. Int J Nanomedicine. 2006; 1 (3): 297-315.

11. Felnerova D, Viret J-F, Gluck R, Moser C. Liposomes and virosomes as delivery systems for antigens, nucleic acids and drugs. Curr Opin Biotechnol. 2004; (15): 518-29.

12. Barenholz Y. Liposome application: problems and prospects Curr Opin Colloid Interface Sci. 2001; (6): 66-77.

13. Vasir JK, Reddy MK, Labhasetwar VD. Nanosystems in drug targeting: opportunities and challenges. Curr Nanoscience. 2005; $1(1): 47-64$

14. Basu MK. Liposomal delivery of antileishmanial agents. J Applied Research. 2005; 5 (1): 221-36.

15. Zurbriggen R, Amacker M, Krammer AR. Immunopotentiating reconstituted influenza virosomes. In: G. Gregoriadis, editor Liposome technology. 3rd edn. Vol. I. Liposome preparation and related techniques. New York: Informa Healthcare USA, 2007; 85-96.

16. Fang J, Sawa T, Maeda H. Factors and mechanism of «epr» effect and the enhanced antitumor effects of macromolecular drugs including smancs. Adv Exp Med Biol. 2003; (519): 29-49.

17. Greish K, Fang J, Inutsuka T et al. Macromolecular therapeutics: advantages and prospects with special emphasis on solid tumour targeting. Clin Pharmacokinet. 2003; (42): 1089-105.

18. Maeda $\mathrm{H}$. The enhanced permeability and retention (epr) effect in tumor vasculature: the key role of tumor-selective macromolecular drug targeting. Adv Enzyme Regul. 2001; (41): 189-207.

19. Haley B, Frenkel E. Nanoparticles for drug delivery in cancer treatment. Urologic Oncology: Seminars and Original Investigations. 2008; (26): 57-64.

20. Ланцова А. В. Создание и биотерапевтическое изучение липосомальных лекарственных форм противоопухолевых препаратов производных нитрозомочевины [диссертация] М., 2006; 173 c.

21. Ланцова А. В., Оборотова Н. А. Перетолчина Н. М. Сравнительное изучение противоопухолевой активности липосомальных лекарственных форм препаратов производных нитрозоалкилмочевины. Сибирский онкологический журнал. 2005; 2 (14): 25-9.

22. Allen TM. Ligand-targeted therapeutics in anticancer therapy. Nat Rev Cancer. 2002; 2 (10): 750-63.

23. Толчева Е. В. Создание конструкции иммунолипосомы и изучение иммунолипосомальной формы противоопухолевого препарата доксорубицин [диссертация]. М., 2007; 109 с.

24. Соколова Д. В., Тазина Е. В., Кортава М. А. Анти-CD40 и анти-HLA-DR иммунолипосомальные формы доксорубицина: технология получения и антигенспецифиичность in vivo. Российский биотерапевтический журнал. 2010; 9 (2): 90.

25. Соколова Д. В., Тазина Е. В., Кортава М. А. и др. Анти-MUC1 иммунолипосомальная форма доксорубицина: технология получения и антигенспецисичность in vitro. Российский биотерапевтический журнал. 2010; 9 (3): 21.

26. Хугаева О. В., Кортава М. А., Соколова Д. В. и др. Получение липосомального митоксантрона. Материалы IX Всеросс. науч.-практ. конф. «Отечественные противоопухолевые препараты». Российский биотерапевтический журнал. 2010; 9 (2): 91.

27. Насонов Е. Л. Перспективы применения ритуксимаба при аутоиммунных заболеваниях человека. Российский медицинский журнал. 2007; 15 (26): 1-6.
28. Соколова Д. В. Иммунолипосомальные конструкции доксорубицина и модели для их доклинического исследования [диссертация]. М., 2011; 122 с.

29. Kawakami S, Fumoto S, Nishikawa M et al. In vivo gene delivery to the liver using novel galactosylated cationic liposomes. Pharmaceuttic Research. 2000; 17 (3): 306-13.

30. Dass CR, Choong PFM. Targeting of small molecule anticancer drugs to the tumor and its vasculature using cationic liposomes: lessons from gene therapy. Cancer Cell Int. 2006; 6 (17): 1-9.

31. Ponce AM, Wright A, Dewhirst MW, Needham D. Targeted bioavailability of drugs by triggered release from liposomes. Future Lipidol. 2006; 1 (1): 25-34.

32. Jain S, Mishra V, Singh P et al. RGD-anchored magnetic liposomes for monocytes/neutrophils-mediated brain targeting. Int J Pharm. 2003; 261 (1-2): 43-55.

33. Qin J, Chen D, Hu H et al. Surface modification of RGD-liposomes for selective drug delivery to monocytes/Neutrophils in brain. Chem Pharm Bull. 2007; 55 (8): 1192-7.

34. Campbell RB, Fukumura D, Brown EB et al. Cationic charge determines the distribution of liposomes between the vascular and extravascular compartments of tumors. Cancer Res. 2002; (62): 6831-6.

35. Ambegia E, Ansell S, Cullis $P$ et al. Stabilized plasmid-lipid particles containing PEG-diacylglycerols exhibit extended circulation lifetimes and tumor selective gene expression. Biochim Biophys Acta. 2005; 1669 (2): 155-63.

36. Dass CR. Improving anti-angiogenic therapy via selective delivery of cationic liposomes to tumor vasculature. Int J Pharm. 2003; 267 (1-2): 1-12.

37. Тазина Е. В., Мещерикова В. В., Игнатьева Е. В. и др. Биофармацевтические исследования термочувствительной липосомальной лекарственной формы доксорубицина Российский биотерапевтический журнал. 2009; 1 (8): 40-7.

38. Huang Z, Szoka FC. Bioresponsive liposomes and their use for macromolecular delivery. In: G. Gregoriadis, editor. Liposome technology. 3rd edn. Vol. I. Liposome preparation and related techniques. New York: Informa Healthcare USA, 2007; p. 165-96.

39. Березов Т. Т., Яглова Н. В., Дмитриева Т. Б. и др. Направленный транспорт лекарственных средств с помощью липосом. Вестник РАМН. 2004; 5: 42-7.

40. Wu D, Pardridge WM. Neuroprotection with noninvasive neurotrophin delivery to the brain. Proc Natl Acad Sci USA. 1999; (96): 254-9.

41. Shi N, Pardridge WM. Noninvasive gene targeting to the brain. Proc Natl Acad Sci USA. 2000; 97 (13): 7567-72.

42. Pal A, Ahmad A, Khan $S$ et al. Systemic delivery of RafsiRNA using cationic liposomes silences Raf in xenograft model of human prostate cancer. Int J Oncol. 2005; 26 (4): 1087-91.

43. Omidi Y, Barar J, Akhtar S. Toxicogenomics of cationic lipidbased vectors for gene therapy: impact of microarray. Curr Drug Del. 2005; 2 (4): 429-41.

44. Oliveira S, Storm G, Schiffelers. Targeted delivery of siRNA. J Biomed Biotechnol. 2006; (2006): 1-7.

45. Miyazaki M, Obata $\mathrm{Y}$, Abe $\mathrm{K}$ et al. Gene transfer using nonviral delivery systems. Perit Dial Int. 2006; (26): 633-40.

46. Aguilar JC. Vaccine adjuvants revisited. Vaccine. 2007; (25): 3752-62.

47. Perrie Y, Frederik PM, Gregoriadis G. Liposome-mediated DNA vaccination: the effect of vesicle composition. Vaccine. 2001; (19): 3301-10.

48. Фармацевтическая разработка: концепция и практические рекомендации. В книге: Быковский С. Н., Василенко И. А., Демина Н. Б., Шохин И. Е., Новожилов О. В., Мешковский А. П., Спицкий О. Р., редакторы. Научно-практическое руководство для фармацевтической отрасли. М.: Перо, 2015; 472 с.

49. Lu D, Hickey AJ. Liposomal dry powders as aerosols for pulmonary delivery of proteins. AAPS Pharm Sci Tech. 2005; 6 (4): 641-8.

50. De Lima MCP, Simoes $S$, Pires $P$ et al. Cationic lipid-DNA complexes in gene delivery: from biophysics to biological applications. Adv Drug Del Rev. 2001; (47): 277-94. 